\title{
Determining of Provable Loss in Municipal Bus Transport and Its Influence on Public Budgets in Sparsely Populated Areas of the Czech Republic
}

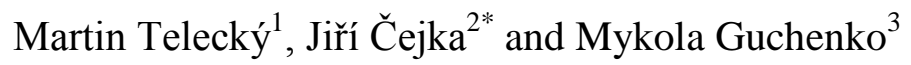 \\ ${ }^{1}$ University of South Bohemia in České Budějovice, Faculty of Economics, Department of \\ Accounting and Finance, 37005 České Budějovice, Czech Republic; Email: \\ martin.telecky@volny.cz. \\ ${ }^{2}$ Institute of Technology and Business in České Budějovice, Faculty of Technology, Department \\ of Informatics and Natural Sciences, Okružní 10, 37001 České Budějovice, Czech Republic; \\ Email: cejka@mail.vstecb.cz. \\ ${ }^{3}$ Kremenchuk Mykhailo Ostrohradskyi National University, Kremenchuk, Ukraine; Email: \\ mykolaguchenko@gmail.com
}

\section{*Corresponding Author: Jiř́i Čejka}

Abstract: This paper is aimed to compare two regulations concerned with the issue of determining the amount of a provable loss or, newly, a compensation, i.e. Government Decree No. 493/2004 Sb., regulating the provable loss in the public line transport and specifying the method of the exercise of the professional government supervision in the road transport over funding the traffic services, and Regulation No. 296/2010 Sb. on the procedures for establishing the financial model and setting the maximum amount of the compensation. Both regulations suggest the different methodology for determining the amount of compensation in a transport company for the accounting period. The goal is to analyse which methodology encourages the explanatory power of individual items of economically substantiated costs and revenues and whether it has a consistent influence on the final value of compensation. The question is raised of whether we can achieve the same or at least a similar amount of compensation if both methodologies of the provable loss or compensation calculation are applied in the municipal bus transport.

Keywords: Bus transport, rural area, public budget, sparsely populated area

\section{Introduction}

One of the basic needs of the human factor - transportation - is satisfied by providing the transport services. The transport companies rendering the transport services provide the client of 
the transport with the information which serves as a comprehensive overview of what is happening right now in the defined region. The accounting methods in the public line and trackbased transport are different in the financial accounting and the managerial accounting. It means that the selected type of transport is specific as to its business activity and the use of its fixed assets. Operating costs in the public line and track-based transports are mostly identical, however, each transport has its own particulars which cannot be applied within a single methodology for determining the amount of compensation. The public track-based transport depends, for instance, on the number of deployed railway wagons which drastically increase the total costs. On the other hand, the public line transport employs the buses which cannot be linked together if the higher number of passengers needs to be transported.

The paper focuses on the public bus transport and the application of the legislation aimed at determining the amount of the provable loss pursuant to Government Decree No. 493/2004 Sb. and Regulation No. 296/2010 Sb. Both documents use the basic methodologies which determine the amount of compensation based on their explanatory power. At the end of the accounting period, transport companies as transport service providers calculate, on the basis of the data taken from their accounts, the amount of compensation (provable loss) laid down in the Report on Costs and Sales from Transport Operations, or on the basis of the real financial model pursuant to Regulation No. 296/2010 Sb. The formal aspects and the content of reports represent the significant shortcoming. Transport companies may misuse the accounting data and may intentionally or unknowingly determine the compensation which is higher than the actual compensation which should be paid out. Creative accounting is, as a result, a common phenomenon in the public transport [1-3].

\section{Methods}

The goal of the paper is to apply the methodology of determining the amount of provable loss pursuant to Government Decree No. 493/2004 Sb. and Regulation No. 296/2010 Sb. The application of the above methodologies will provide the final answer to the question: Which methodology will result in higher demands for paying out the higher amounts of money from public budgets [1-3]. 


\subsection{Government Decree No. 493/2004 Sb.}

The urban public transport is provided by means of the carriers ordered by the municipal office or municipality. Its introduction is not required by law. The budgets of towns and municipalities which are directly related to funding of the provable loss and adequate profit for the transport companies or private carriers must be settled every year. The municipal councils are obliged to approve of the extent of traffic services and are responsible for ensuring the transport within their areas.

The provable loss is covered from public budgets (of municipalities and regions); more exact terms and conditions for payment of the loss are provided in the public service contract concluded between the client and the carrier. In case of the public line transport, the "provable loss" term is defined (pursuant to Government Decree No. 493/2004 Sb.) as the difference between the sum of the economically substantiated costs and the modified adequate profit and the earned receipts and revenue.

The adequate profit is calculated using the following formula:

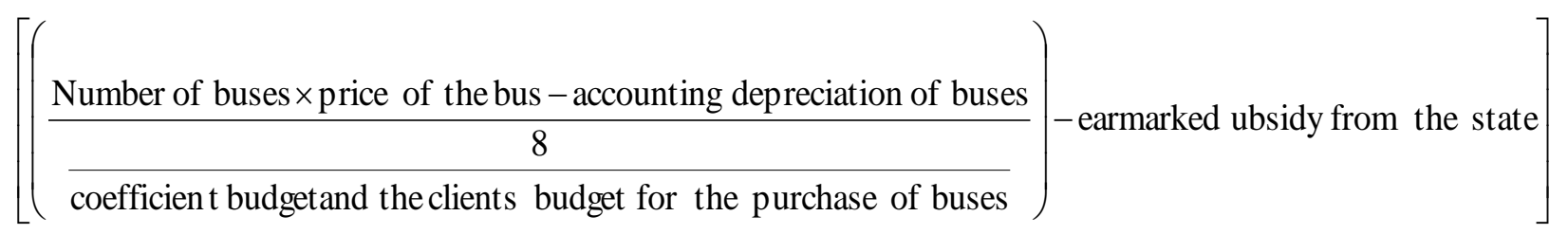

The coefficient is calculated as follows:

$$
\frac{100-\% \text { of income tax }}{100}
$$

The coefficient is used for the needs of including the corporate income tax.

Under the contract, the carriers are allowed to be paid out the adequate profit, which is designed only to support the renewal of vehicles in the public line transport and the urban public transport (buses) in the 8-year cycle. As well as the provable loss, the adequate profit cannot be spent on any other business purposes. It is understood as an option of obtaining the financial means (resources) for the rolling stock renewal [4-10]. 


\subsection{Regulation No. 296/2010 Sb.}

The Regulation No. 296/2010 on the procedures for establishing the financial model and determining the maximum amount of compensation supersedes the term "provable loss and the adequate profit" by the term "amount of compensation." Under the new regulation, the carrier is required to submit to the client all information on the situation of its assets related to providing the traffic services, the performance and all activities. The carrier is thus more intensively controlled and the more demanding requirements are applied. Newly, each carrier is required to report all of its operating assets before making the contract. This necessity was not directly required in the regulation No. 493/2004 Sb. The reason for reporting operating assets is a new requirement for not exceeding the maximum permissible rate of return per the capital, being $7.5 \%[1,3]$.

Regulation No. 296/2010 Sb. requires that every carrier submits to the client the situation of its assets, or more precisely the state of operating assets which the carrier directly uses to ensure the traffic services. This requirement is satisfactory as the maximum amount of compensation is established in this way. Upon the amortised cost the client receives the information on the age of the rolling stock and, finally, provides higher compensation for the renewal of the older rolling stock with partially new vehicles $[1,3]$.

Economically substantiated costs are identical in both documents. There are, however, exceptions, i.e. which economically substantiated costs should not be included in the methodology of calculating the compensation pursuant to Regulation No. 296/2010 Sb. It is especially the costs generated by the means of transport not owned by the carrier. Pursuant to Government Decree No. 493/2004 Sb., this requirement could be breached if the means of transport are used from $80 \%$ to ensure traffic services [2,3].

\subsection{Input Data}

To determine the amount of compensation according to the methodologies [11,12], we have chosen a fictitious transport company which is very close to the transport reality in the conditions of the Czech Republic. The Table 1 includes the basic classification of economically substantiated costs, receipts or revenue and the number of kilometres travelled by all means of transport according to the timetable. The owner of the transport company (or, more precisely, a municipal office) is supposed to pay $80 \%$ of the provable loss or compensation and the region or 
other municipalities pay $20 \%$ of the payment. Table 1 also shows the report on the costs and revenue from the transport operation in 2017. Figures are in thousands of units.

Table 1 Report on the costs and revenue from the transport operations in 2017. Source: authors

\begin{tabular}{|c|c|c|c|c|c|c|c|c|}
\hline \multirow{3}{*}{\multicolumn{2}{|c|}{ Item }} & \multirow{3}{*}{ Line } & \multicolumn{6}{|c|}{ Bus transport in $20 \mathrm{xx}$} \\
\hline & & & \multicolumn{2}{|c|}{ Town } & \multicolumn{2}{|c|}{ Outside the town } & \multicolumn{2}{|c|}{ Total } \\
\hline & & & thousand & $\mathrm{CZK} / \mathrm{k}$ & thousan & $\mathrm{CZK} / \mathrm{k}$ & thousan & $\mathrm{CZK} / \mathrm{k}$ \\
\hline & Fuel & 1 & 24,000 & 10.00 & 5,700 & 9.83 & 29,700 & 9.97 \\
\hline & Tyres & 2 & 1,350 & 0.56 & 250 & 0.43 & 1,600 & 0.54 \\
\hline Oth & er direct material, energy & 3 & 8,300 & 3.46 & 2,100 & 3.62 & 10,400 & 3.49 \\
\hline & Direct wages & 4 & 37,000 & 15.42 & 9,100 & 15.69 & 46,100 & 15.47 \\
\hline \multirow{5}{*}{ Buses } & $\begin{array}{l}\text { Depreciation of the urban public } \\
\text { transport vehicles }\end{array}$ & 5 & 18,500 & 7.71 & 4,700 & 8.10 & 23,200 & 7.79 \\
\hline & Lease of means of transport & 6 & 0 & 0.00 & 0 & 0.00 & 0 & 0.00 \\
\hline & Repairs and maintenance of buses & 7 & 23,500 & 9.79 & 5,700 & 9.83 & 29,200 & 9.80 \\
\hline & Road tax & 8 & 0 & 0.00 & 0 & 0.00 & 0 & 0.00 \\
\hline & $\begin{array}{l}\text { Insurance (accident, statutory, } \\
\text { collision) }\end{array}$ & 9 & 1,400 & 0.58 & 350 & 0.60 & 1,750 & 0.59 \\
\hline \multirow{3}{*}{$\begin{array}{l}\text { Other } \\
\text { direct costs }\end{array}$} & $\begin{array}{c}\text { Fare } \\
\end{array}$ & 10 & 0 & 0.00 & 0 & 0.00 & 0 & 0.00 \\
\hline & Payments to the funds & 11 & 12,600 & 5.25 & 3,100 & 5.34 & 15,700 & 5.27 \\
\hline & Any other direct costs & 12 & 250 & 0.10 & 100 & 0.17 & 350 & 0.12 \\
\hline & Overhead costs & 13 & 19,600 & 8.17 & 4,800 & 8.28 & 24,400 & 8.19 \\
\hline \multicolumn{2}{|r|}{ Total operating costs } & 14 & 146,500 & 61.04 & 35,900 & 61.90 & 182,400 & 61.21 \\
\hline \multirow{3}{*}{ Sales } & Total & 15 & 53,650 & 22.36 & 13,120 & 22.62 & 66,770 & 22.41 \\
\hline & Sales from transportation & 16 & 53,200 & 22.17 & 13,000 & 22.41 & 66,200 & 22.21 \\
\hline & Other receipts and revenue & 17 & 450 & 0.19 & 120 & 0.21 & 570 & 0.19 \\
\hline \multirow{3}{*}{$\begin{array}{c}\text { Payment of } \\
\text { the } \\
\text { provable } \\
\text { loss of the } \\
\text { urban } \\
\text { public } \\
\text { transport }\end{array}$} & into total receipts and revenue & 18 & & & & & 115,630 & 38.80 \\
\hline & From the municipal office & 19 & & & & & 92,504 & 31.04 \\
\hline & $\begin{array}{l}\text { From the regional office and } \\
\text { municipalities }\end{array}$ & 20 & & & & & 23,126 & 7.76 \\
\hline \multicolumn{2}{|c|}{ Loss paid from the pupils' fare } & $20 \mathrm{a}$ & & & & & & \\
\hline \multicolumn{2}{|c|}{ Adequate profit for bus renewal } & 21 & & & & & 21,037 & 7.06 \\
\hline \multicolumn{2}{|c|}{$\begin{array}{l}\text { Subsidies into the receipts for renewal of buses } \\
\text { by way of leasing }\end{array}$} & $21 \mathrm{a}$ & & & & & & \\
\hline \multicolumn{2}{|c|}{$\begin{array}{c}\text { Mileage (thousand } \mathrm{km} \text { ) (according to the } \\
\text { timetable }+ \text { technology) }\end{array}$} & 22 & \multicolumn{2}{|c|}{2,400} & \multicolumn{2}{|c|}{580} & \multicolumn{2}{|c|}{2,980} \\
\hline
\end{tabular}

Traffic services are supposed to be provided in both the town and outside the town in sparsely populated areas. The total mileage as per the timetable amounts to 2,980,000 kilometres. 
Another requirement of the client and Regulation No. 296/2010 Sb. is to submit the Report on Operating Assets (Table 2 in thousands of units) as well as the information on the adequate profit calculation (Table 3) pursuant to Government Decree No. 493/2004 [3].

Table 2 Report of Operating Assets. Source: authors

\begin{tabular}{l|r|r|r}
\hline $\begin{array}{c}\text { Operating asset } \\
\text { definition }\end{array}$ & $\begin{array}{c}\text { Percentage of use of the } \\
\text { assets to ensure the } \\
\text { obligation }\end{array}$ & $\begin{array}{r}\text { Net book value in the immediately } \\
\text { preceding accounting period (in thousand } \\
\text { CZK) }\end{array}$ \\
\hline Means of transport & $100 \%$ & 140,000 & 140,000 \\
\hline Buses & $100 \%$ & 140,000 & 140,000 \\
\hline Total & $89 \%$ & 43,610 & 49,000 \\
\hline Other assets & $88 \%$ & 286,880 & 326,000 \\
\hline Land & & $\mathbf{0}$ \\
\hline Buildings (Structures) & & $\mathbf{0}$ \\
\hline Other fixed assets & & & $\mathbf{5 1 5 , 0 0 0}$ \\
\hline First extraordinary lease payments
\end{tabular}

The Table 2 shows the basic data on the percentage of the use of operating assets only for ensuring the traffic services. Other operating costs which are not related to traffic services must be separated in the accounts and taken out of this report. The values of assets are provided in the net book value as of the immediately preceding accounting period. The land and buildings are not fully used assets; they are used only partially.

Table 3 Basic data for calculation of adequate profit pursuant to Government Decree No. 493/2004 Sb. Source: authors

\begin{tabular}{l|l|l}
\hline Number of buses & number of deployed vehicles & 56 \\
\hline Average price & $\begin{array}{l}\text { Calculation as per the type of employed vehicles in } \\
\text { thousand CZK }\end{array}$ & 5,020 \\
\hline $\begin{array}{l}\text { Annual accounting } \\
\text { depreciation }\end{array}$ & $\begin{array}{l}\text { Depreciation of means of transport, including the departure } \\
\text { control systems in thousand CZK }\end{array}$ & 18,100 \\
\hline Subsidies & Expected subsidy in purchase of vehicles & 0 \\
\hline Coefficient & Tax due calculated from adequate profit for the next year & 0.81 \\
\hline Denominator "8" & expresses the 8-year renewal cycle & 8 \\
\hline
\end{tabular}

Table 3 shows the number of total deployed means of transport, average price of buses, annual depreciation of all operating assets used, etc. The coefficient is 0.81 . The corporate income tax rate is $19 \%$ as per the applicable Income Tax Act No. 586/1992 Sb. The denominator "8" represents the 8-year cycle of rolling stock renewal. 


\section{Results}

\subsection{Determining of Provable Loss Pursuant to Government Decree No. 493/2004 Sb.}

The adequate profit calculation is governed by the valid data contained in Table 3.

Namely,

$\left\lceil\frac{56 \text { buseg }}{85.020}-18.100\right] / / 0.81=\mathbf{2 1 , 0 3 7}$ thousand CZK.

The adequate profit amounts to $21,037,000 \mathrm{CZK}$. The total provable loss is calculated on the basis of the following formula:

Provable loss $=$ total costs - receipts $($ revenue $)+$ adequate profit $=182,400-66,770+$ 21,037 = 136,667 thousand CZK.

As a result, the municipal office and the region or other municipalities participate in the disbursement of 136,667,000 CZK, i.e. 45.86 CZK/kilometre travelled. Lines 19, 20 and 21 in Table 1 show the disbursement of a provable loss and adequate profit by the municipal office $(80 \%)$ and the region $(20 \%)$ in a total amount and in the value as per one kilometre travelled due to a better explanatory power of the report $[2,3]$.

\subsection{Determining of the Amount of Compensation Pursuant to Regulation No. 296/2010 Sb.}

The figures from the report are the same, however, the Regulation does not reckon with the calculation of an adequate profit in this case. Regulation No. 296/2010 Sb. takes account of the term "net income" which amounts to $7.5 \%$ of operating assets at most. The following definition applies: "rate of return per the capital: $7.5 \%$ of operating assets".

The compensation will be calculated as follows:

Compensation $=$ total costs - total receipts $($ revenue $)+$ net income $=182,400-66,770+35,287$ $=150,917$ thousand CZK.

The net income is determined from the details in Table 2, i.e. from the report of operating assets. The calculation was set as $7.5 \%$ of 470,490 thousand CZK. The net income amounts to 35,287 thousand CZK. The requirement of the rate of return per the capital of $7.5 \%$ of operating assets is met.

\section{Conclusion}


The paper mentions the main differences between Government Decree No. 493/2004 Sb. and Regulation No. 296/2010 Sb. These two regulations served as the basis for calculating the provable loss and the compensation. The total value of a provable loss is $136,667,000 \mathrm{CZK}$ and the compensation amounts to 150,917,000 CZK. This implies that Regulation No. 296/2010 Sb. promotes faster renewal of the rolling stock, however, with a higher share of financial means spent from the public budgets, i.e. by 14,250,000 CZK more. At present, there are many transport companies which determine the provable loss pursuant to Government Decree No. 493/2004 Sb. Until November 2010, they used the basic formula for the adequate profit calculation. This requirement is still valid, however the addenda to the public service contracts are newly made. These addenda require from the carriers to report the annual operating assets pursuant to Regulation No. 296/2010 Sb. despite the fact that this requirement was not necessary within Government Decree No. 493/2004 Sb. More detail terms and conditions of determining and payment of the provable loss or compensation are provided in the public service contract made between the carrier and the client, including the conditions for determining the amount of the net income pursuant to Regulation No. 296/2010 Sb.

\section{Acknowledgments}

Note: The publication was created in connection with the project solution CE 55 - Rumobil.

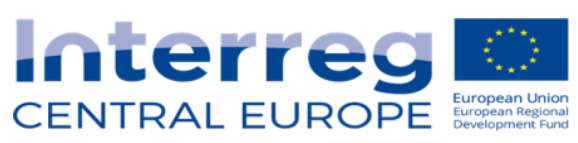

\section{RUMOBIL}

\section{References}

[1] Decree of the Czech Republic Government No. 493/2004 Sb. regulating the provable loss in the public line transport and establishing the method of exercise of the professional government supervision in the road transport over funding of the traffic services.

[2] Telecký, M. (2016). Factors Affecting Financial Health of Public Transport Companies from the Viewpoint of Accounting, Financing and Other Disciplines, $1^{\text {st }}$ issue, $152 \mathrm{p}$. České Budějovice: University of South Bohemia in České Budějovice, Faculty of Economics, Department of Accounting and Finances. 
[3] Regulation No. $296 / 2010 \mathrm{Sb}$. on the procedures for establishing the financial model and determining the maximum amount of compensation.

[4] Methodology and indicator calculation method for sustainable urban mobility. World Business Council for Sustainable Development. Project 2.0 (SMP2.0), WBCSD, 2015.

[5] Kolosz, B. \& Grant-Muller, S. (2015). Extending cost-benefit analysis for the sustainability impact of inter-urban Intelligent Transport Systems. Environmental Impact Assessment, 50, 167-177.

[6] Jespersen-Groth, J., Potthoff, D., Clausen, J, Huisman, D., Kroon, L., Maróti, G. \& Nielsen M.N. (2009). Disruption Management in Passenger Railway Transportation. In Robust and Online Large-Scale Optimization, LNCS; Ahuja, R., Möhring, R., Zaroliagis, C., Eds.; Vol. 5868 (pp. 399-421), Springer International Publishing: Berlin, Germany.

[7] Fotr, J. \& Svecova, L. (2010). Managerial Decision-Making (Manažerské rozhodování. Procedures, Methods and Tools (Postupy, metody a nástroje in czech). Prague: Ekopress, s. r. o. 478 p. ISBN 978-80-86929-59-0.

[8] Petrik, T. (2009). Economic and Financial Management of the Company (Ekonomické a finanční řizení firmy in czech). Managerial Accounting in Practice (Manažerské účetnictví v praxi) - 2nd extensively extended and updated issue. Prague: GradaPublishing, 736 p. ISBN 978-80-247-3024-0.

[9] Valach, J. (2006). Investment Decision-Making and Long-term Financing (Investiční rozhodování a dlouhodobé financování in czech), 2nd reworked issue. Prague: Ekopress, s. r. o., 465 p. ISBN 80-86929-01-9.

[10] Otrusinova, M. \& Steker, K. (2016). How to Read Accounting Reports - Fundamentals of Czech Accounting and Reporting (Jak číst účetní výkazy - Základy českého účetnictví a výkaznictví in czech), 288 p. ISBN 978-80-271-0048-4.

[11] Troncoso, R. \& de Grange, L. (2017). Fare evasion in public transport: A time series approach. Transportation Research Part A-Policy and Practice, 100, 311-318. DOI: 10.1016/j.tra.2017.04.029.

[12] Gupta, S. \& Mukherjee, A. (2013). Utilization of passenger transport subsidy in Kolkata: A case study of Calcutta State Transport Corporation. Research in Transportation Economics, 38(1), 3-10. DOI: 10.1016/j.retrec.2012.05.011. 